\title{
TEXTURED UHMWPE SURFACE TO REDUCE THE WEAR OF A KNEE PROSTHESIS
}

\author{
ZMANJŠANJE OBRABE KOLENSKE PROTEZE S \\ TEKSTURIRANJEM POVRŠINE POLIETILENA Z ULTRA VISOKO \\ MOLEKULARNO MASO (UHMWPE)
}

\author{
Tomas De la Mora Ramírez ${ }^{1,3}$, Marco A. Doñu Ruiz², Noé López Perrusquia², \\ Ernesto García Bustos ${ }^{4}$, Martín Flores Martínez ${ }^{4}$, Daniel Maldonado Onofre ${ }^{3}$, \\ Isaias Hilerio Cruz ${ }^{1}$ \\ ${ }^{1}$ Metropolitan Autonomous University, Azcapotzalco Unit, Mexico City \\ ${ }^{2}$ Polytechnic University of the Valley of Mexico, Tultitlán de Mariano Escobedo, Mexico \\ ${ }^{3}$ Toluca-Atlacomulco KM Highway 44.8, Ejido de San Juan y San Agustín, 50700 Jocotitlán, Mexico \\ ${ }^{4}$ CONACYT Chairs, University of Guadalajara, University Center for Exact Sciences and Engineering, blvd. Marcelino García Barragán \\ \#1421, esq. Calzada Olímpica, C.P. 44430, Guadalajara, Jalisco, Mexico \\ Prejem rokopisa - received: 2019-08-19; sprejem za objavo - accepted for publication: 2020-09-15
}

doi:10.17222/mit.2019.194

\begin{abstract}
A morphological modification of the surface texture of ultra-high-molecular-weight polyethylene (UHMWPE) was carried out to improve its tribological properties. Laboratory tests were conducted with specimens manufactured with $3 \mathrm{D}$ printing using a polyethylene material for knee prosthesis parts, type GUR 1020, with circular geometric textures of 224 micrometers in diameter, at different distances between the centers of the cylinder with respect to a uniform distribution on the surface of a specimen called geometric density, and at $(5,10,20$ and 40) \% saturation of the geometries on the surfaces. The wear was analyzed by means of 3D profilometry, obtaining the wear rate, while the wear constant was obtained from the laboratory tests and was used to determine which geometric density is the most suitable. The finite-element method was used to analyze the contact pressure, which is a great criterion for the selection of the texture. The results indicate that samples with texture densities of $10 \%$ followed by $5 \%$ exhibit a decrease in the wear volume.

Keywords: ultra-high-molecular-weight polyethylene, knee prosthesis, texturizing, tribology
\end{abstract}

Avtorji članka so izboljšali tribološke lastnosti polietilena z visoko molekularno maso (UHMWPE) z morfološko modifikacijo njegove površinske teksture. Laboratorijske preizkuse so izvajali na vzorcih, ki so bili izdelani s tehnologijo 3D tiska. Pri tem so uporabili polietilenski material primeren za dele kolenskih protez tipa GUR 1020 s krožno geometrično teksturo premera 224 mikronov, $\mathrm{z}$ različno medsebojno razdaljo valjčkov in $\mathrm{z}$ njihovo enakomerno razporeditvijo na površini vzorcev, tako da so dobili različno geometrijsko gostoto nasičenja površine $(5,10,20$ in 40) \%. Obrabo so analizirali s 3D profilometrijo in pri tem določili hitrost in konstanto obrabe. Na ta način so lahko z laboratorijskimi preizkusi določili katera geometrijska gostota je najprimernejša. Z metodo končnih elementov so analizirali kontaktni tlak, ki je najboljši kriterij za izbiro teksture. Rezultati raziskave kažejo, da imajo vzorci s teksturno gostoto $10 \%$, katerim sledi $5 \%$ najmanjšo volumsko obrabo.

Ključne besede: polietilen z ultra visoko molekularno maso, kolenska proteza, teksturiranje, tribologija

\section{INTRODUCTION}

UHMWPE has been used in orthopaedics as one of the materials for artificial joints for 50 years. ${ }^{1}$ However, the main problem of knee prostheses is the fact that the half-life of their components made of UHMWPE is approximately 15 years., ${ }^{2,3}$ The polyethylene particles generated by the contact and sliding of the metal in a prosthesis joint are the most common inducers of osteolysis, which leads to imminent failure of the piece. ${ }^{4}$ For this reason, several ways to increase the life of a prosthesis have been studied; among them the modification of the surface topography of orthopedic elements stands out, playing an important role in the contact between the surfaces of the pieces and considerably influencing their wear. ${ }^{5}$ The most recent research on textured surfaces has

*Corresponding author's e-mail:

tomas.delamora@tesjo.edu.mx (Tomas De La Mora) yielded the following results: Menezes investigated the tribological properties of UHMWPE with textured surfaces, obtaining the $\mathrm{COF}$ and the formation of a transfer film by varying the surface texture, reporting that it has a lower friction coefficient compared to a non-textured surface. ${ }^{6}$ Lbatan studied the effect of texture on the improvement of tribological performance for a lubricated and non-lubricated system due to the fact that microcavities, which act as deposits of the residue and lubricant, applied to bearing components, ${ }^{7}$ increase the load capacity $^{8}$ due to the decrease of the contact area., ${ }^{9,10}$ Tanu Suryadi worked on the frictional wear of the UHMWPE implanted in a prosthesis, improving the morphological structure with the texture of the polymer surface through nano-impression lithography (NIL). He performed reciprocal wear tests, concluding that the COF was reduced, being between $8 \%$ and $35 \% .{ }^{11}$ 


\section{EXPERIMENTAL PART}

The material used for the tests was of the GUR 1020 type, which was supplied by a knee prosthesis manufacturer, Break Fix Trauma from Mexico.

Cylindrical holes in the textured surface were used, leading to notable benefits such as (1) retention of the lubricant, ${ }^{12}(2)$ the fact that the deposit of the wear residue could minimize the effect of a greater damage to the surfaces due to abrasive wear, ${ }^{13}$ (3) increase in the hydrodynamic pressure, ${ }^{14}$ (4) a decrease in the contact area, reducing adherence ${ }^{15}$ and (5) easy manufacture and low $\operatorname{costs}^{16}$. Tribological properties depend on the density, depth and dimension of the geometry. ${ }^{17,18}$

The density of the geometric area is the number of craters per square area on the surface of a specimen. It is one of the main parameters for surface texturization, directly influencing the contact area, the number of lubricant deposits and the amount of material removed as a result of abrasive wear. ${ }^{16}$

Density percentages were used. The length between the centers (L) and the depth of the crater (hd) were obtained with equations (1) and (2), respectively: ${ }^{19,10}$

$$
L=\sqrt{\frac{\text { area } a_{\text {circular geometry }}}{\delta_{\text {circle }}}}
$$

where $L$ is the length between the centers of the geometry, the area of the geometry is $\pi r^{2}$ and the circular densityis $\delta_{\text {circle }}=(5,10,20$ or 40$) \%$.

To calculate the depth of the crater, the following equation was used:

$h_{\mathrm{d}}=\left(\delta_{\text {circular }}\right)(L) h_{\mathrm{d}}=\left(d_{\text {circular }}\right)(L) h_{\mathrm{d}}=\left(\delta_{\text {circular }}\right)(L)$

In this investigation, a specimen with a circular geometry including a constant diameter $(d)$ of $200 \mu \mathrm{m}$, a variable depth $h_{\mathrm{d}}$ and an area for printing the geometries on the surface of the specimen of $9 \mathrm{~mm}^{2}$ were used (Figure 1).

Table 1 shows the values of the variables used for the calculation of the textures with the constant dimensions of the diameter and varying density of area to obtain the distance between the center of the circles and their depth using equations (1) and (2).
Table 1: Values of the variables used to manufacture the textures of test specimens

\begin{tabular}{|c|c|c|c|}
\hline $\begin{array}{c}\text { Area density } \\
\delta(\%)\end{array}$ & $\begin{array}{c}\text { Diameter } d \text { of } \\
\text { the circumfer- } \\
\text { ence }(\mu \mathrm{m})\end{array}$ & $\begin{array}{c}\text { Distance be- } \\
\text { tween geome- } \\
\text { try centers } \\
L(\mu \mathrm{m})\end{array}$ & $\begin{array}{c}\text { Depth of ge- } \\
\text { ometry } \\
h d(\mu \mathrm{m})\end{array}$ \\
\hline 5 & 200 & 1590 & 79 \\
\hline 10 & 200 & 1210 & 121 \\
\hline 20 & 200 & 800 & 160 \\
\hline 40 & 200 & 560 & 224 \\
\hline
\end{tabular}

With the data from Table 1, 3D specimens were made on a Polijet Objet 3D 4000 printer, to be used in a laboratory micro-abrasion test. The printer can print biocompatible polymers (Figure 1). A UHMWPE bar, used for the manufacture of knee-tumor prostheses, was ground into pellets and then molded into $1.75 \mathrm{~mm}$ diameter filaments to be used in the printer as the consumable raw material. At the time of printing, the molding temperature was $200{ }^{\circ} \mathrm{C}$ and the deposition speed was $2 \mathrm{~mm} / \mathrm{s}$. 3D specimens with different textures were manufactured to be used in the micro-abrasion test (Figure 1).

Finite-element tests were performed using simulation software to analyze the contact pressure that occurred during the micro-abrasion test. The surface texture influences the contact pressures and deformations, so the values that do not exceed the elastic limit are sought. The simulations were carried out based on the configuration and shape of the wear-test equipment in the laboratory. A three-dimensional model of a ball and a flat test tube were used to perform a static analysis of the textures with the proposed densities. The sphere exhibited the properties of the 52100 steel with a Young's modulus of $200000 \mathrm{MPa}$, a Poisson's ratio of 0.3 and a density of 7800 ton $/ \mathrm{mm}^{3}$. The UHMWPE specimen had a Young's modulus of $1080 \mathrm{MPa}$, a Poisson's ratio of 0.4 and a density of 9.7 e-10 ton $/ \mathrm{mm}^{3}$. These properties were configured with the simulation software. A ball-and-cylinder model was used to perform a static texture analysis of the proposed densities.

In the simulation tests, a load of $5 \mathrm{~N}$ was used at 1000,2000 and 4000 cycles, equivalent to $79.79,159.58$

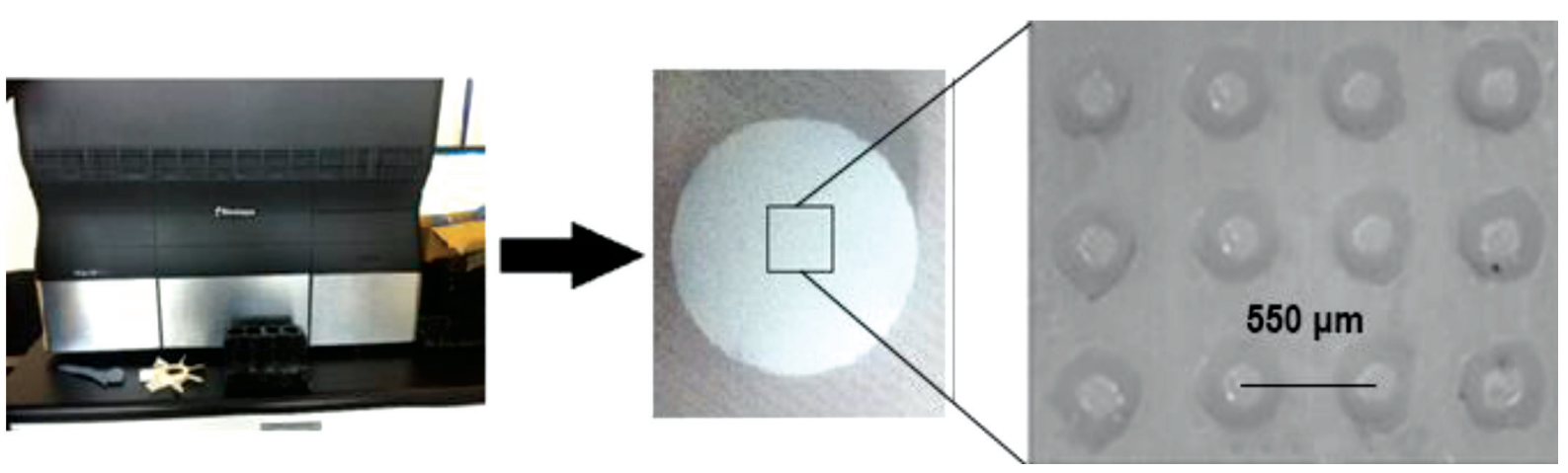

Figure 1: Objet 3D 4000 machine and a printed specimen with a circular texture 
and 319.16 linear meters traveled, respectively, at different percentages of the proposed textures.

With a $3 \mathrm{D}$ profilometry analysis, the profile of the marks obtained with the micro-abrasion tests was obtained and the volume of wear was calculated for each condition applied in the abrasion tests. The diameter of different wear marks was determined by measuring the wear mark seen in the plane perspective; the depth of the wear mark was measured with the transversal profile and a Temporal P15 profilometer was used. With the wear-volume Equation (3) developed by Hutchings and derived from the contact model proposed by Archard, the lost volume was obtained: ${ }^{21}$

$$
V=\pi h^{2} \frac{(3 D / 2-h)}{3}
$$

where $D$ is the diameter of the ball of the micro-abrasion test and $\mathrm{h}$ is the depth of the crater resulting from the test.

The wear coefficient $\mathrm{k}$ can be determined with the classic wear model, developed by F. Archard in $1953^{21}$ (Equation (4)):

$$
k=\frac{V}{S N}
$$

where $V$ is the wear volume, $S$ is the sliding distance and $N$ is the normal force. Three tests were made for each of the samples under the following conditions: 10 drops of lubricant were added every 100 cycles, each drop being equivalent to $1.228 \pm 0.075 \mathrm{~mL}$ of a $5 \mathrm{gm}$ mixture of alumina with a size of $5 \mu \mathrm{m}$, with a solution of $10 \mathrm{~g}$ glucose, $1 \mathrm{~g}$ sodium chloride and $85 \mathrm{~mL}$ distilled water at an abrasive wheel rotation speed of $1 \mathrm{~m} / \mathrm{min}$.

\section{RESULTS AND DISCUSSION}

\subsection{Contact-pressure analysis of the texturing of the specimens with the finite-element method}

The results for the contact pressure show an increase with the geometric density, achieving $57.35 \mathrm{MPa}$ in the $40 \%$ density condition. The textures with densities of 5 and $10 \%$ were exposed to a lower contact pressure compared to the non-textured specimens. These results agree with Xiong, who indicated that the texture-density values below $10 \%$ are optimal for improving the tribological properties of a piece..$^{22}$ Therefore, the favorable texture for improving the wear is $5 \%$, with a pressure of 33.49 $\mathrm{MPa}$ (Figure 2).

One effect to consider in the case of textured specimens is the detachment of the material by the edges of circular geometries, which is greater than that of a non-textured surface. Textured surfaces are exposed to less friction but greater wear since the crater edges favor this loss of the material whose surface interacts with another, smooth one, which is confirmed by the results of contact-pressure stresses. ${ }^{22,23}$

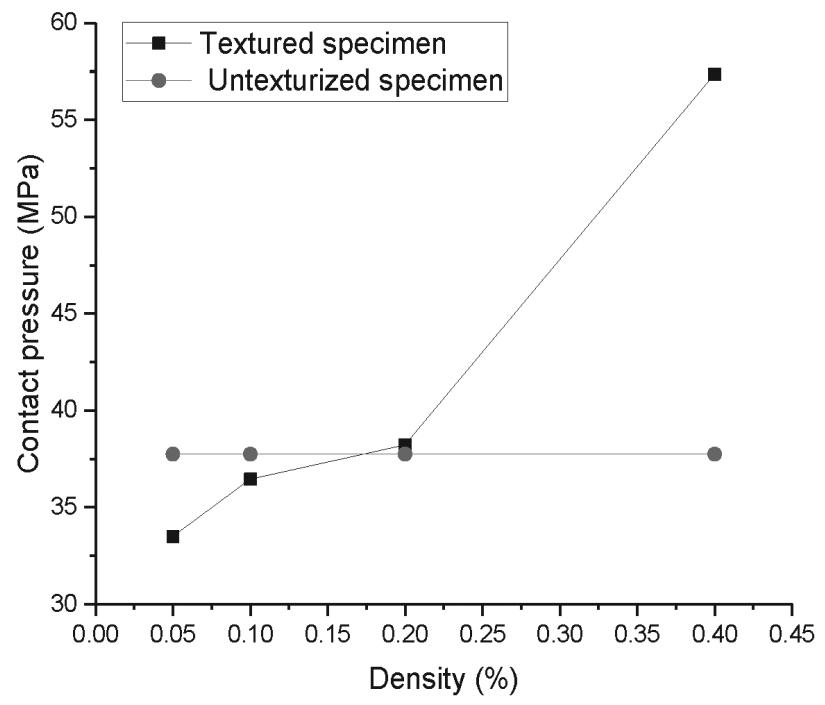

Figure 2: Graph of contact pressure versus density

The depth of the optimal textures is $18 \mu \mathrm{m}$ and 25 $\mu \mathrm{m}$, respectively, determining that low depth values give a low coefficient of friction. ${ }^{24}$ Another reason for the stress increase in the textured samples with a high geometric density is that, due to the circular shape, the crater perimeters are stress concentrators.

\subsection{Tribological tests of micro-abrasion}

The specimens with different texture densities were analyzed with optical profilometry. The wear height was obtained through the Vision software, processing the data in .DAT format obtained in with the 3D optical profilometer. The wear volume was calculated by measuring the diameter and depth of the wear crater and applying Hutchings' Equation (3). ${ }^{20}$

Figure 3b shows the marks of the cylindrical geometries in the light-blue zone left after the $5 \mathrm{~N}-4000$ cycle micro-abrasion test. It is possible to see the grooves made by the particles contained in the abrasive fluid.

Figure 4 of the wear-volume graph shows that the texture density that improves the tribological characteristics of UHMWPE is $10 \%$, followed by the density of 5 $\%$ for the cycles used. The minimum value of the volume of wear is $0.0104 \pm 1.7 \mathrm{e}-4 \mathrm{~mm}^{3}$ after 1000 cycles for the $10-\%$ texture, and the maximum of $0.00714 \pm 9.48 \mathrm{e}-5$ $\mathrm{mm}^{3}$ after 4000 cycles was found for the $40-\%$ density

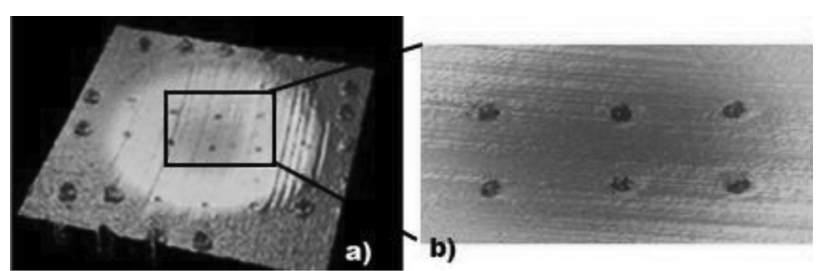

Figure 3: Optical-profilometer images of the sample with a $5 \%$ density texture: a) $5 \mathrm{~N}-4000$ cycles and b) craters with a density of $5 \%$ after the abrasion test 


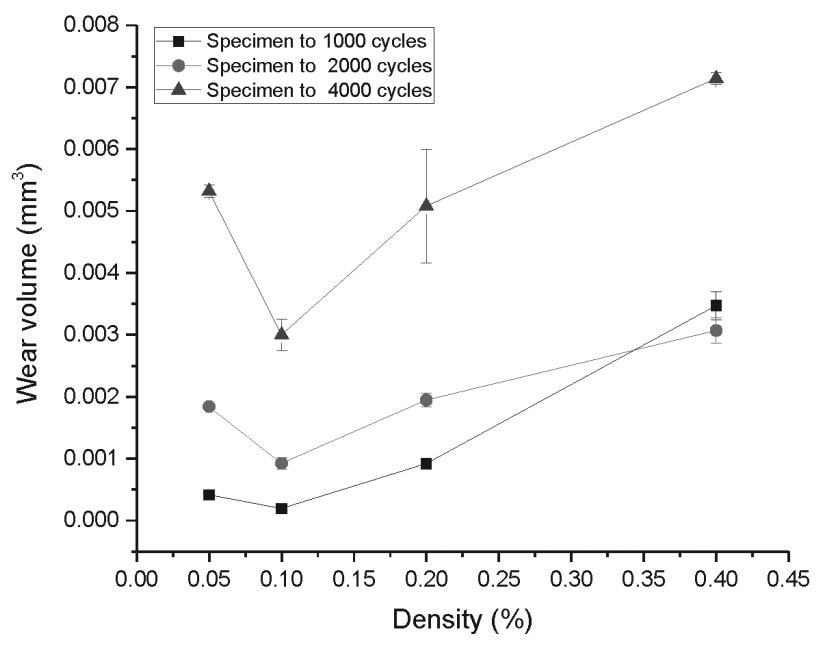

Figure 4: Graphical wear volume of the textured specimens

textures. Under all the conditions experienced, the density resulting in the least volume of wear was found for the specimen printed with a density of $10 \%$ and a depth of $121 \mu \mathrm{m}$.

\section{DISCUSSION}

Comparing the micro-abrasion tests of the textured versus non-textured specimens, the main variable of the wear volume indicates that in the condition of $5 \mathrm{~N}$ and 4000 cycles imposed on the 40-\% textured specimens, the maximum wear volume is $0.00714 \pm 9.48 \mathrm{e}-5 \mathrm{~mm}^{3}$, while the non-textured specimen has a wear volume of $0.781 \mathrm{~mm}^{3}$ under the same test conditions, indicating that texturing significantly reduces the wear rate.

The specimens with densities of $40 \%$ have a greater volume of wear due to distances or numerous long cycles, causing a greater detachment of UHMWPE particles, which are the main inducers of osteolysis. Berli indicates that the roughness of artificial joints is a considerable factor. The textures with densities of $(5,10$ and 40) \% have a high coefficient of friction compared to the test piece without the texture. ${ }^{6}$ This was confirmed with the contact-pressure results of the finite-element analysis.

The textures with a density of $40 \%$ show higher values of abrasion wear because there is a greater amount of the material released as a result of the number of cylinders per unit square area and the perimeter of the circular geometries functions as the stress concentrator affecting the surface discontinuity. ${ }^{25}$ We can conclude that the volume of wear depends largely on the density and the normal load applied. The textures with a 5-\% density have a greater depth of wear (h) compared to the non-textured sample in the same experimental condition. It should be noted that 5-\% textured surfaces exhibit a significant contact-pressure-reduction effect compared to 20- and $40-\%$ textures. Surface-texturization studies carried out by different authors indicate that the most optimal tex- tures for reducing the wear are greater than $20 \%$ and lower than $50 \%,{ }^{22,23}$ and according to reference ${ }^{27}$ and Figure 4 included in this work, the same result is achieved by limiting the dimple density for a specimen exposed to 4000 cycles to between $40 \%$ and $50 \%$, leading to the optimum result.

Another task to consider is to improve the durability of artificial joints with highly wear-resistant coatings as proposed by Muzamil, which can be achieved using the methodologies of reinforcement with carbon nanoparticles, leading to an improvement in the functionality of an orthopedic implant. Likewise, the results reported in the literature relating to UHMWPE textures showed that texturization is an important method for improving the friction and wear resistance of contact surfaces, requiring us to study the influence of textures on the mechanical properties and lifetime of a prosthesis. ${ }^{28}$

The depths of 79 and $121 \mu \mathrm{m}$ are most suitable for improving tribological properties. This result coincides with Anderson, who says that low depths result in a low coefficient of friction ${ }^{24}$. The contact point between the surfaces of the sphere and the flat sample during the first cycles in the abrasion test indicates that there is little or no penetration of the abrasive fluid used in this area. First, there is adhesive wear, exhibiting low values of the wear volume, regardless of the load applied. Under the conditions of more than 2000 cycles, abrasive wear occurs because abrasive particles interact between the two surfaces causing a three-body abrasive wear. ${ }^{26}$

\section{CONCLUSIONS}

The optimal textures for improving tribological properties, obtained with the finite-element analysis, are those with densities of $5 \%$ and $10 \%$.

The contact pressure was lower for the specimens with textures of densities of $5 \%$ and $10 \%$.

Under conditions of more than 2000 cycles, threebody abrasive wear occurs.

Graphically, it can be shown that the geometry with a density of $10 \%$ is the most suitable for the cycles used as it leads to low values of the wear volume under sliding conditions.

\section{Acknowledgements}

Our gratitude goes to CONACYT for the scholarship for completing the $\mathrm{PhD}$ in materials science and engineering at the Metropolitan Autonomous University, the University Center for Exact Sciences and Engineering of the University of Guadalajara for the use of laboratory equipment and company BREAK FIX Trauma de Mexico for the material and use of the prosthesis for the research project and to the Technological Institute of Higher Studies of Jocotitlan for financing the publication of the article and for the use of the additive-manufacturing laboratory. 


\section{REFERENCES}

${ }^{1}$ S. Kurtz, M. K. Orhun, Advances in the processing, sterilization, and crosslinking of ultra-high molecular weight polyethylene for total joint arthroplasty, Biomaterials, (1999), 1658-88, doi:10.1016/ S0142-9612(99)00053-8

${ }^{2}$ J. Baena, J. Wu, Wear Performance of UHMWPE and Reinforced UHMWPE Composites in Arthroplasty Applications: A Review, Lubricants, (2015), 413-436, doi:10.3390/lubricants3020413

${ }^{3}$ O. Buehler, E. Venn, The press-fit condylar total knee system: 8- to 10-year results with a posterior cruciate-retaining design, J. Arthroplasty, (2000), 698-701, doi:10.1054/arth.2000.8189

${ }^{4}$ M. Ulrich-Vinther, E. Carmody, Recombinant adeno-associated virus-mediated osteoprotegerin gene therapy inhibits wear debris-induced osteolysis, J. Bone Joint Surg. Am., (2002), 1405-12, doi:10.2106/00004623-200208000-00016

${ }^{5} \mathrm{M}$. Berli, Influencia de la rugosidad superficiales en el desgaste de las prótesis de rodilla, XV Congreso Argentino de Bioingeniería, 2005, 69

${ }^{6} \mathrm{P}$. Menezes, Role of surface texture and roughness parameters on friction and film formation when UHMWPE sliding against steel, Science Direct, (2016), 1-10, doi:10.1016/j.bsbt.2016.02.001

${ }^{7} \mathrm{~T}$. Ibatan, Recent development on surface texturing in enhancing tribological performance of bearing sliders, Elsevier, 2015, 102-120, doi:10.1016/j.surfcoat.2015.04.017

${ }^{8} \mathrm{U}$. Pettersson, Influence of surface texture on boundary lubricated sliding contacts, Tribology, (2003), 857-864, doi:10.1016/S0301679X(03)00104-X

${ }^{9}$ J. Jamari, Study the effect of surface texturing on the stress distribution of UHMWPE as a bearing material during rolling motion, American Institute of Physics, (2016), 150-157, doi:10.1063/ 1.4945484

${ }^{10}$ N. Lazim, Determination of simple distribution for laser texturing process on cast iron surface, Proceedings of Mechanical Engineering Research Day, 2016, 146-146, doi:10.1016/j.triboint.2013.10.006

${ }^{11} \mathrm{~T}$. Kustandi, Texturing of UHMWPE surface via NIL for low friction and wear properties, Journal of Physics, (2009), 1-5, doi:10.1088/0022-3727/43/1/015301

${ }^{12} \mathrm{X}$. Kato, Tribological properties of surface dimple-textured by pellet-pressing, SciencieDirect, (2009), 1513-18, doi:10.1016/j.proeps. 2009.09.233
${ }^{13}$ P. Nam, Control of friction, Wear, (1994), 151-158, doi:10.1016/ 0043-1648(94)90178-3

${ }^{14}$ X. Wang, The Lubrication Effect of Micro-Pits on Parallel Sliding Faces of SiC in Water, Tribology Transactions, (2008), 294-301, doi:10.1080/10402000208982552

${ }^{15}$ R. Ranjan, Laser texturing for low-flying-height media, Journal of Applied Physics, (1998), 135-148, doi:10.1063/1.347908

${ }^{16} \mathrm{~J}$. Yan, Fabricating micro-structured surface by using single-crystalline diamond endmill, Int. J. Adv. Manuf. Technol., (2010), 957-64, doi:10.1007/s00170-010-2695-2

${ }^{17} \mathrm{~B}$. Kim, Effects of surface texturing on the frictional behavior of cast iron surfaces, Tribology International, (2014), 128-135, doi:10.1016/j.triboint.2013.10.006

${ }^{18}$ F. Rodríguez, Tesis: Diseño de superficies texturizadas óptimas para la lubricación de contactos mecánicos, Madrid: Universidad Politécnica de Madrid, 2016

${ }^{19}$ Y. Zhanga, Numerical study of surface texturing for improving tribological properties of ultra-high molecular weight polyethylene, ScienceDirect, Elseiver, (2015), 270-277, doi:10.1016/j.bsbt. 2015.11.003

${ }^{20}$ M. Hutchings, Friction and Wear of Engineering Materials, Tribology, (1999), 233-235

${ }^{21}$ J. Archard, Contact and rubbing of flat surfaces, Journal of Applied Physics, http://link.aip.org/link/?JAPIAU/24/981/1 [Accessed September 23, 2010], doi:10.1063/1.1721448, 2010

${ }^{22}$ D. Xiong, Tribological properties of PTFE/laser surface texturing on rolling contact, Tribology, (2015), 305-310, doi:10.1016/j.triboint. 2014.07.017

${ }^{23}$ A. Kovalchenko, The effect of laser surface texturing on transition in lubrication regimes during undirectional sliding contact, Tribology, (2005), 219-225, doi:10.1016/j.triboint.2004.08.004

${ }^{24} \mathrm{P}$. Anderson, Microlubrication effect by laser-textured steel surface, Wear, (2007), 369-379, doi:10.1016/j.wear.2006.06.003

${ }^{25}$ B. Hamrock, Elementos de máquinas, McGraw-Hill, México 2000

${ }^{26}$ A. L. Galvin, L. Kang, Effect of conformity and contact stress on wear in fixed-bearing total knee prostheses, Journal of Biomechanics, (2009), 1898-1902, doi:10.1016/j.jbiomech.2009.05.010

${ }^{27}$ Y. Haiwu, X. Wang, Geometric Shape Effects of Surface Texture on the Generation of Hydrodynamic Pressure between Conformal Contacting Surfaces, Tribol. Lett., (2010), 123-130, doi:10.1007/ s11249-009-9497-4 